\title{
PENGARUH KECEMASAN MATEMATIS DAN KONSEP DIRI TERHADAP HASIL BELAJAR MATEMATIKA SISWA
}

\author{
${ }^{1}$ Annisa Juliyanti, ${ }^{2}$ Heni Pujiastuti \\ Universitas Sultan Ageng Tirtayasa, Jl. Ciwaru Raya No.25, Cipare, Kec. Serang, Kota Serang, Banten 42117 \\ (0254) 280330, Indonesia \\ e-mail: annisajuliyanti18@gmail.com
}

\begin{abstract}
Abstrak
Penelitian ini menguji pengaruh kecemasan matematis dan konsep diri terhadap hasil belajar matematika siswa. Penelitian ini merupakan penelitian kuantitatif, populasi dalam penelitian ini adalah seluruh siswa kelas XII Madrasah Aliyah Al-Islah, tahun ajaran 2019/2020. Pengambilan sampel dalam penelitian ini dilakukan dengan teknik simple random sampling (sampel acak sederhana) yaitu cara pengambilan sampel secara acak (random) dengan benar-benar memberikan peluang yang sama. Jenis data yang digunakan dalam penelitian ini ialah data kuantitatif berupa kecemasan matematis, konsep diri dan hasil belajar matematika siswa. Untuk memperoleh data tersebut, peneliti menggunakan dua metode pengumpulan data kuantitatif, yakni metode dokumentasi dan metode angket. Berdasarkan hasil pengolahan data, didapat bahwa nilai signifikansi untuk kecemasan matematis sebesar $0,016<0,05$, dan nilai signifikansi untuk konsep diri sebesar $0,230>0,05$. Ini berarti bahwa secara parsial hanya faktor kecemasan matematis yang memberikan pengaruh terhadap hasil belajar matematika siswa. Sedangkan berdasarkan uji analisis regresi berganda diperoleh nilai $F_{\text {hitung }}$ sebesar 3,758 dengan nilai signifikansinya $0,044<$ 0,05 sehingga terdapat pengaruh yang signifikan antara kecemasan matematis dan konsep diri secara simultan terhadap hasil belajar matematika siswa. Diperoleh nilai $\mathrm{R}^{2}$ sebesar 0,308 , artinya $30,8 \%$ perubahan pada hasil belajar matematika siswa secara simultan dengan kecemasan matematis dan konsep diri, sedangkan 69,2\% sisanya dijelaskan oleh berbagai macam variabel lain yang tidak dianalisis dalam penelitian ini.
\end{abstract}

Kata Kunci: Kecemasan matematis, Konsep diri, Hasil belajar matematika

\begin{abstract}
This study examines the effect of mathematical anxiety and self-concept on student mathematics learning outcomes. This study is quantitative; the population in this study were all students of class XII Madrasah Aliyah Al-Islah, academic year 2019/2020. Sampling in this study was carried out with a simple random sampling technique (simple random sampling) that is a way of taking samples randomly (random) by actually providing the same opportunities. The type of data used in this study is quantitative data in the form of mathematical anxiety, self-concept, and student mathematics learning outcomes. To obtain this data, researchers used two quantitative data collection methods, namely the documentation method and the questionnaire method. Based on the results of data processing, it was found that the significance value for mathematical anxiety was $0.016<0.05$, and the significance value for self-concept was $0.230>0.05$. This means that partially only mathematical anxiety factors that influence student mathematics learning outcomes. While based on the multiple regression analysis tests, the $\mathrm{F}_{\text {coun }}$ t value of 3.758 was obtained with a significance value of $0.044<0.05$ so that there was a significant influence between mathematical anxiety and self-concept simultaneously on student mathematics learning outcomes. The obtained $\mathrm{R}^{2}$ value of 0.308 , meaning $30.8 \%$ changes in student mathematics learning outcomes simultaneously with mathematical anxiety and self-concept, while the remaining $69.2 \%$ is explained by various other variables not analyzed in this study.
\end{abstract}

Keywords: Mathematical anxiety, Self-concept, Mathematics learning outcomes

\section{PENDAHULUAN}

Salah satu mata pelajaran yang dianggap sulit oleh sebagian besar siswa yaitu matematika, karena sifatnya yang abstrak dan penuh dengan rumus (Ekawati, 2015). Banyak faktor yang menjadi penyebab siswa tidak menyukai mata pelajaran matematika, di antaranya sifat matematika yang abstrak, penuh angka, rumus, dan memerlukan latihan. Cara 
penyampaian materi yang digunakan guru saat ini juga masih banyak yang menggunakan pendekatan konvensional, sehingga pembelajaran matematika yang diajarkan terkesan kaku dan membosankan, hal tersebut juga dapat menyebabkan siswa tidak menyukai mata pelajaran matematika dan sebagian siswa menganggap matematika sebagai pelajaran yang sulit dan menakutkan (Wahyudy, Putri, \& Muqodas, 2019). Sebagian siswa juga berpendapat bahwa pelajaran matematika merupakan pelajaran yang sulit dimengerti, dan tidak menarik, sehingga sebelum pembelajaran, siswa sudah dihinggapi rasa takut terlebih dahulu yang menyebabkan kesulitan dalam berkonsentrasi.

Dampak negatif dari ketidaksukaan siswa terhadap matematika yaitu timbulnya rasa cemas ketika belajar matematika, rasa cemas yang dialami siswa pada mata pelajaran matematika disebut juga sebagai kecemasan matematis. Kecemasan biasanya akan muncul jika siswa menghadapi situasi yang dianggapnya mengancam. Kondisi tersebut akan membuat siswa beranggapan yang negatif terhadap dirinya sendiri. Siswa yang merasa cemas berlebihan sering kali menjadikan matematika sebagai mata pelajaran yang dihindari (Priyani, 2013).

Kecemasan matematis merupakan suatu perasaan tidak nyaman yang muncul akibat dari emosi yang tidak stabil yang ditandai dengan rasa khawatir, tegang, takut, dan was-was ketika mengahadapi suatu kegiatan yang tidak dikehendakinya dalam pembelajaran matematika (Wahyudy, et al., 2019). Kecemasan adalah perasaan emosional yang begitu dominan yang dialami oleh seseorang dalam kaitannya dengan pembelajaran matematika (Apriliani \& Suyitno, 2016). Kecemasan matematis merupakan perasaan cemas, takut dan tidak nyaman yang muncul akibat emosi yang tidak stabil yang ditandai dengan rasa khawatir, tegang, takut, dan was-was ketika menghadapi suatu kegiatan yang tidak dikehendakinya dalam kaitannya dengan pembelajaran matematika

Siswa yang mengalami kecemasan matematis cenderung menghindari kondisi di mana mereka merasa terancam dan tertekan, tentunya orang tersebut akan berpikiran atau berangggapan yang negatif terhadap dirinya sendiri. Kecemasan dapat berdampak baik ketika masih terkendali dan tergolong wajar, karena kinerja fisik dan intelektual siswa didorong dan diperkuat oleh kecemasan. Berdampak buruk ketika tidak terkendali dan tingkat kecemasan berlebihan, kecemasan seperti ini membuat siswa sulit berkonsentrasi (Priyani, 2013). Kecemasan matematis tidak dapat diabaikan begitu saja, karena siswa yang tidak mampu beradaptasi pada pelajaran matematika menyebabkan siswa kesulitan serta takut terhadap pelajaran matematika yang akhirnya menyebabkan hasil belajar dalam matematika rendah.

Terdapat beberapa faktor yang memengaruhi hasil belajar siswa, di antaranya faktor dalam diri siswa dan faktor yang berkaitan dari luar diri siswa. Faktor dalam diri siswa seperti 
bakat, minat, motivasi, konsep diri dan lain-lain dan faktor yang berkaitan dari luar seperti faktor dari dalam rumah maupun lingkungan sekitarnya (Andinny, 2015). Konsep diri merupakan salah satu faktor penting dalam mencapai keberhasilan. Konsep diri merupakan suatu kepercayaan mengenai keadaan diri sendiri yang relatif sulit diubah (Handayani, 2016). Terbentuknya konsep diri berdasarkan dari suatu pengalaman yang didapat oleh seseorang dari keluarga, lingkungan maupun ketika di sekolah (Andinny, 2015). Konsep diri terbagi menjadi dua jenis yaitu, konsep diri positif dan konsep diri negatif. Seseorang yang memiliki konsep diri positif dapat menerima dirinya dengan apa adanya, bersyukur atas kelebihan dan ikhlas akan kekurangannya, sedangkan seseorang yang memiliki konsep diri negatif kurang dapat menerima kekurangan diri sendiri sehingga kecewa terhadap kekurangan-kekurangan yang ada pada dirinya sendiri, akibatnya menjadi minder dan rendah diri.

Konsep diri pada mata pelajaran matematika merupakan suatu penilaian siswa terhadap kemampuan dirinya sendiri dan rasa suka atau ketertarikan terhadap matematika (Magfirah, Rahman, \& Sulasteri, 2015). Seseorang yang memiliki konsep diri positif lebih semangat, penuh percaya diri dan cenderung bersikap positif terhadap sesuatu, juga terhadap kegagalan yang dialami dalam pembelajaran matematika, sedangkan seseorang yang memiliki konsep diri negatif cenderung mudah menyerah, pesimis dan rendah diri terhadap kemampuan dirinya sendiri dalam menyelesaikan permasalahan matematika. Konsep diri negatif dapat berpengaruh buruk terhadap hasil belajar matematika siswa.

Kecemasan matematis biasanya akan muncul jika individu menghadapi situasi yang dianggapnya mengancam dan menekan (Leonard, \& U.S., 2010). Ketika kondisi di mana rasa cemas itu muncul, orang tersebut akan beranggapan yang negatif terhadap dirinya sendiri. Kecemasan matematis dan konsep diri merupakan faktor dalam diri siswa yang mempengaruhi hasil belajar matematika siswa.

Hasil belajar sering kali digunakan sebagai tolak ukur seseorang untuk mengetahui seberapa paham dan menguasai bahan yang diajarkan (Disai, Dariyo, \& Basaria, 2017). Hasil yang didapat siswa yang telah mengikuti proses pembelajaran matematika disebut dengan hasil belajar matematika. Pentingnya hasil belajar matematika yaitu untuk mengukur apakah pembelajaran yang selama ini dilakukan berhasil atau tidak (Ikhsan, 2019). Hasil belajar matematika siswa dapat dilihat apabila tujuan-tujuan dari pembelajaran yang telah ditetapkan dapat dicapai oleh siswa, dan sebaliknya apabila sebagian besar siswa tidak dapat mencapai tujuan-tujuan dari pembelajaran berarti hasil pembelajaran tidak tercapai. Berdasarkan uraianuraian di atas mengenai kecemasan matematis, konsep diri dan hasil belajar matematika, maka 
tujuan dari penelitian ini adalah untuk mengetahui ada tidaknya pengaruh kecemasan matematis dan konsep diri terhadap hasil belajar matematika siswa.

\section{METODE PENELITIAN}

Penelitian ini merupakan penelitian kuantitatif, populasi dalam penelitian ini adalah seluruh siswa kelas XII Madrasah Aliyah Al-Islah, tahun ajaran 2019/2020. Pengambilan sampel dalam penelitian ini dilakukan dengan teknik simple random sampling (sampel acak sederhana) yaitu cara pengambilan sampel secara acak (random) dengan benar-benar memberikan peluang yang sama. Jenis data yang digunakan dalam penelitian ini ialah data kuantitatif berupa kecemasan matematis, konsep diri dan hasil belajar matematika siswa. Untuk memperoleh data tersebut, peneliti menggunakan dua metode pengumpulan data kuantitatif, yakni metode dokumentasi dan metode angket.

Metode dokumentasi digunakan untuk pengambilan data hasil belajar matematika siswa, sedangkan metode angket digunakan untuk memperoleh data kecemasan matematis dan konsep diri. Angket kecemasan matematis terdiri dari dua aspek, yaitu aspek psikologis dan aspek fisiologis, sedangkan angket konsep diri terdiri dari tiga aspek, yaitu aspek fisik, aspek psikologis, dan aspek sosial. Data kecemasan matematis dan konsep diri kemudian dikategorikan berdasarkan kategori tinggi, sedang, dan rendah. Adapun skala pengukuran kecemasan matematis yang digunakan dalam penelitian ini yaitu skala Likert. Pengolahan dan analisis data dimaksudkan untuk mencari kuatnya pengaruh antara variabel melalui analisis regresi berganda, sebelum melaksanakan analisis perlu dilakukannya pengujian prasyarat analisis regresi yang meliputi uji normalitas, uji linearitas, dan uji multikolinieritas.

Analisis regresi berganda adalah alat analisis yang digunakan untuk mengetahui besarnya pengaruh variabel independen, yaitu kecemasan matematis $\left(\mathrm{X}_{1}\right)$ dan konsep diri $\left(\mathrm{X}_{2}\right)$ terhadap variabel dependen yaitu hasil belajar matematika siswa (Y). Dalam penelitian ini metode analisis regresi linear berganda digunakan untuk mengetahui pengaruh antara kecemasan dan konsep diri secara bersama-sama dengan hasil belajar matematika siswa.

\section{HASIL DAN PEMBAHASAN}

Kecemasan dan konsep diri dapat diketahui dari hasil pengsisian angket yang disebarkan pada siswa, sedangkan untuk data hasil belajar matematika siswa diperoleh dari hasil penilaian akhir semester. Hasil dari penilaian akhir semester dan pengisian angket tersebut dapat membedakan kecemasan matematis dan konsep diri yang terdiri dari tinggi, sedang dan rendah. 
Adapun setelah melakukan pengumpulan data dengan membagikan instrumen angket pada siswa, diperoleh pengelompokkan data sebagai berikut:

Tabel 1. Sebaran Skor Kecemasan Matematis

\begin{tabular}{ccc}
\hline Kecemasan Matematis & Frekuensi & Presentase \\
\hline Tinggi & 3 & $15 \%$ \\
Sedang & 17 & $85 \%$ \\
Rendah & 0 & 0 \\
\hline Jumlah & 20 & $100 \%$ \\
\hline
\end{tabular}

Berdasarkan Tabel 1, dapat diketahui bahwa sebagian besar siswa mempunyai kecemasan pada kategori sedang. Hal tersebut terlihat dari adanya 17 orang siswa berada pada kategori sedang, 3 orang siswa berada pada kategori tinggi dan tidak ada siswa yang memiliki kategori kecemasan rendah. Perbedaan tingkat atau kategori kecemasan matematis dikarenakan setiap individu memiliki latar belakang kehidupan yang berbeda-beda, karena kecemasan matematis seseorang dapat dipengaruhi oleh beberapa faktor seperti lingkungan, emosi yang ditekan dan sebab-sebab fisik.

Tabel 2. Sebaran Skor Konsep Diri

\begin{tabular}{ccc}
\hline Konsep Diri & Frekuensi & Presentase \\
\hline Tinggi & 5 & $25 \%$ \\
Sedang & 12 & $60 \%$ \\
Rendah & 3 & $15 \%$ \\
\hline Jumlah & 20 & $100 \%$ \\
\hline
\end{tabular}

Berdasarkan Tabel 2, dapat diketahui bahwa sebagian besar siswa mempunyai konsep diri pada kategori sedang. Hal tersebut terlihat dari 12 orang siswa berada pada kategori sedang, 5 orang siswa berada pada kategori tinggi, dan ada 3 orang siswa yang memiliki kategori konsep diri rendah. Perbedaan tingkat atau kategori konsep diri dikarenakan setiap individu memiliki kondisi kehidupan yang berbeda-beda, karena konsep diri seseorang dapat dipengaruhi oleh beberapa faktor seperti keluarga, teman, suasana kelas bahkan pandangan siswa mengenai guru yang akan mengajar (Rehanja, 2017).

Tabel 3. Deskripsi Data Hasil Belajar Matematika Siswa

\begin{tabular}{lcccc}
\hline & N & Minimum & Maximum & Mean \\
\hline Hasil Belajar Matematika Siswa & 20 & 67 & 90 & 81.40 \\
\hline
\end{tabular}

Berdasarkan Tabel 3, diperoleh rata-rata hasil belajar matematika siswa sebesar, 81,40. Nilai hasil belajar siswa tertinggi yaitu 90, sedangkan nilai hasil belajar siswa terendah yaitu 67. Berikutnya hasil angket kecemasan matematis dan konsep diri serta data hasil belajar matematika siswa di uji normalitas dengan menggunakan Kolomogorv-Smirnov dengan taraf signifikansinya 0,05 . 
Tabel 4. Uji Normalitas

\begin{tabular}{lcc}
\hline & Statistic & Sig \\
\hline One-Sample Kolmogorov-Smirnov Test & 2,012 & 0,167 \\
\hline
\end{tabular}

Dari Tabel 4 diketahui bahwa nilai signifikansi uji normalitas sebesar 0,167>0,05, maka dapat diartikan bahwa data tersebut berdistribusi normal. Selanjutnya, data tersebut diuji liniearitasnya, untuk mengetahui pengaruh antara kecemasan matematis dan konsep diri terhadap hasil belajar matematika siswa bersifat linear atau tidak.

Tabel 5. Uji Linearitas

\begin{tabular}{lcc}
\hline & statistic & Sig \\
\hline Deviation from Linearity & 14,273 & 0,67 \\
\hline
\end{tabular}

Berdasarkan Tabel 5 diketahui bahwa nilai signifikansi uji linearitas sebesar 0,67 >0,05, karena nilai sig lebih besar dari 0,05 maka data tidak terjadi penyimpangan terhadap linieritas. Kesimpulan data memenuhi asumsi klasik sebagai syarat analisis regresi berganda

Tabel 6. Uji Multikolinieritas

\begin{tabular}{ccc}
\hline Variabel & Tolerence & VIF \\
\hline Kecemasan Matematis & 0,936 & 1,068 \\
Konsep Diri & 0,936 & 1,068 \\
\hline
\end{tabular}

Dari Tabel 6 diketahui tidak terjadi masalah multikolinieritas karena nilai VIF $=1,068$ berada disekitar angka 1 dan nilai toleransinya sebesar 0,936 mendekati 1 , sehingga dapat diduga bahwa antar variabel bebas tidak terjadi persoalan multikolinearitas, sehingga dapat disimpulkan bahwa antara variabel bebas tidak terjadi gejala multikolinearitas. Artinya tidak terjadi korelasi antara variabel-variabel bebas, sehingga analisis dapat dilanjutkan. Untuk mengetahui pengaruh antara kecemasan matematis, konsep diri dan hasil belajar matematika siswa, maka data tersebut diuji dengan uji analisis korelasi dan analisis regresi berganda.

Tabel 7. Uji Analisis Korelasi Parsial

\begin{tabular}{lcc}
\hline \multicolumn{1}{c}{ Variabel } & $\mathbf{t}$ & Sig \\
\hline Kecemasan Matematis & 0,119 & 0,016 \\
Konsep Diri & 1,324 & 0,230 \\
\hline
\end{tabular}

Dari Tabel 7, diperoleh nilai signifikansi untuk kecemasan matematis, sebesar 0,016 < 0,05, maka artinya kecemasan matematis berpengaruh signifikan terhadap hasil belajar matematika siswa secara parsial, dengan demikian untuk mendapat hasil belajar matematika yang tinggi, siswa harus menekan atau mengendalikan kecemasan. Nilai signifikansi dari konsep diri sebesar 0,230>0,05 artinya konsep diri tidak berpengaruh signifikan terhadap hasil belajar matematika siswa secara parsial, dengan demikian untuk mendapat hasil belajar matematika siswa yang tinggi tidak dipengaruhi oleh tinggi atau rendahnya tingkat konsep diri. 
Ini berarti bahwa secara parsial hanya faktor kecemasan matematis yang memberikan pengaruh terhadap hasil belajar matematika siswa.

Tabel 8. Uji Analisis Regresi Berganda

\begin{tabular}{cccc}
\hline $\mathbf{R}$ & $\mathbf{R}^{\mathbf{2}}$ & $\mathbf{F}_{\text {Hitung }}$ & Sig \\
\hline 0,555 & 0,308 & 3,785 & 0,044 \\
\hline
\end{tabular}

Dari Tabel 8, diperoleh nilai $\mathrm{R}$ sebesar 0,555, dapat disimpulkan bahwa terdapat pengaruh yang cukup antara kecemasan matematis, konsep diri terhadap hasil belajar matematika siswa. Berdasarkan uji analisis regresi berganda, diperoleh nilai $F_{\text {hitung }}$ sebesar 3,758 dengan nilai signifikansinya $0,044<0,05$ sehingga terdapat pengaruh yang signifikan antara kecemasan matematis, konsep diri secara simultan terhadap hasil belajar matematika siswa. Diperoleh nilai $\mathrm{R}^{2}$ sebesar 0,308 artinya $30,8 \%$ perubahan pada hasil belajar matematika siswa secara simultan dengan kecemasan matematis dan konsep diri, sedangkan 69,2\% sisanya dijelaskan oleh berbagai macam variabel lain yang tidak dianalisis dalam penelitian ini. Dapat disimpulkan bahwa terdapat pengaruh yang cukup dan signifikan antara kecemasan matematis dan konsep diri secara simultan terhadap hasil belajar matematika siswa. Artinya, bahwa tinggi rendahnya hasil belajar matematika siswa berhubungan dengan tinggi rendahnya tingkat konsep diri dan kecemasan matematis.

Hasil ini sejalan dengan penelitian (Priyani, 2013), yang menyatakan hubungan antara konsep diri dan kecemasan menghadapi pembelajaran matematika dengan prestasi belajar matematika menunjukkan adanya hubungan yang signifikan. Hasil penelitian lebih lanjut menemukan bahwa tinggi rendahnya hasil belajar siswa berpengaruh dengan tinggi rendahnya kecemasan matematis dan konsep diri, untuk mendapat hasil belajar matematika yang tinggi, siswa harus mempunyai konsep diri yang tinggi disertai dengan kecemasan yang terkendali atau rendah.

Guru dan orang tua berperan penting dalam membimbing siswa agar dapat melatih cara pandang yang positif tentang dirinya sendiri, siswa dengan cara pandang yang positif tentang dirinya akan mampu mengontrol tingkat kecemasannya, sehingga siswa yang mampu mengontrol tingkat kecemasannya akan berhasil dalam hasil belajarnya (Handayani, 2016). Ketika kecemasan dapat terkontrol, siswa dapat lebih mempersiapkan diri dalam pembelajaran. Namun, ketika siswa tidak dapat mengontrol tingkat kecemasannya menyebabkan siswa kesulitan serta takut terhadap pelajaran matematika yang akhirnya menyebabkan hasil belajar dalam matematika rendah. 
Orang tua berperan dalam membentuk cara pandang anak terhadap dirinya. Salah satu caranya dengan menunjukkan ekspresi rasa sayang dengan memberikan sanjungan, pujian dan penghargaan terhadap setiap usaha dan keberhasilan anak, hal tersebut akan menyebabkan penilaian yang positif terhadap diri anak. Sedangkan ejekan, cemoohan, dan hardikan menyebabkan penilaian yang negatif terhadap diri anak tersebut (Setianingsih, 2017).

Guru sebagai pendidik sangat berperan dalam menentukan proses pembelajaran sehingga pembelajaran yang dilakukan dapat melibatkan siswa dalam memahami dan memaknai konsep setiap topik pembelajaran matematika yang dipelajari (Rigusti \& Pujiastuti, 2020). Keharusan bagi seorang guru sebagai pendidik melakukan inovasi dalam pembelajaran matematika sangat diperlukan karena pembelajaran menyenangkan dan menghilangkan kesan menakutkan, sehingga siswa tidak merasa tertekan dan hal tersebut juga akan berpengaruh terhadap hasil belajar matematika siswa.

\section{SIMPULAN DAN SARAN}

Berdasarkan hasil penelitian dapat disimpulkan bahwa terdapat pengaruh yang signifikan antara kecemasan matematis terhadap hasil belajar matematika siswa secara parsial, berarti untuk mendapatkan hasil belajar matematika yang tinggi, siswa harus menekan atau mengendalikan kecemasannya. Sedangkan konsep diri tidak memiliki pengaruh yang signifikan terhadap hasil belajar matematika siswa secara parsial, dengan demikian untuk mendapat hasil belajar matematika siswa yang tinggi tidak dipengaruhi oleh tinggi atau rendahnya tingkat konsep diri. Berdasarkan uji analisis regresi berganda, terdapat pengaruh yang cukup dan signifikan antara kecemasan matematis dan konsep diri secara simultan terhadap hasil belajar matematika siswa. Artinya, bahwa tinggi rendahnya hasil belajar matematika siswa berhubungan dengan tinggi rendahnya tingkat konsep diri dan kecemasan matematis.

\section{DAFTAR PUSTAKA}

Andinny, Y. (2015). Pengaruh konsep diri dan berpikir positif terhadap prestasi belajar matematika siswa. Jurnal Formatif, 3(2), 126-135.

Apriliani, L. R., \& Suyitno, H. (2016). Kemampuan berpikir kreatif matematis berdasarkan kecemasan matematika pada pembelajaran creative problem solving berteknik scamper. Ujmer, 5(2), 131-140.

Disai, W. I., Dariyo, A., \& Basaria, D. (2017). Hubungan antara kecemasan matematika dan self-efficacy dengan hasil belajar matematika siswa sma x kota Palangka Raya. Jurnal 
Muara Ilmu Sosial, Humaniora, Dan Seni, 1, 556-568.

Ekawati, A. (2015). Pengaruh kecemasan terhadap hasil belajar matematika siswa kelas vii smpn 13 Banjarmasin 1. Math Didactic:Jurnal Pendidikan Matematika, 1(3), 164-169.

Handayani, S. D. (2016). Pengaruh konsep diri dan kecemasan siswa terhadap pemahaman konsep matematika. Formatif: Jurnal Ilmiah Pendidikan MIPA, 6(1), 23-34. https://doi.org/10.30998/formatif.v6i1.749

Ikhsan, M. (2019). Pengaruh kecemasan matematis terhadap hasil belajar matematika siswa. De Fermat:Jurnal Pendidikan Matematika, 2(1), 1-6.

Leonard, \& Supardi U.S. (2010). Pengaruh konsep diri, sikap siswa pada matematika, dan kecemasan siswa terhadap hasil belajar matematika. Cakrawala Pendidikan, 341-352. https://doi.org/10.1007/s002669900030

Magfirah, I., Rahman, U., \& Sulasteri, S. (2015). Pengaruh konsep diri dan kebiasaan belajar terhadap hasil belajar matematika siswa kelas viii smp negeri 6 Bontomatene kepulauan Selayar. MaPan:Jurnal Matematika dan Pembelajaran, 3, 103-116.

Priyani, Y. (2013). Hubungan antara konsep diri dan kecemasan menghadapi pembelajaran matematika dengan prestasi belajar matematika. Universitas Negeri Yogyakarta.

Rehanja, M. (2017). Pengaruh konsep diri akademis terhadap hasil belajar siswa pada mata pelajaran ekonomi. Jurnal Pendidikan dan Pembelajaran Khatulistiwa, 6(9), 1-11.

Rigusti, W., \& Pujiastuti, H. (2020). Analisis kemampuan pemecahan masalah ditinjau dari motivasi belajar matematika siswa. Prima:Jurnal Pendidikan Matematika, 4(1), 1-10.

Setianingsih, D. N. (2017). Comparison of adolescent self-concept who have single parents men and women in sma 76 Jakarta. FamilyEdu, 1(2), 74-90.

Wahyudy, M. A., Putri, H. E., \& Muqodas, I. (2019). Penerapan pendekatan concrete-pictorialabstract (сра) dalam menurunkan kecemasan matematis siswa sekolah. Simposium Nasional Ilmiah \& Call for Paper Unindra (Simponi)., 228-238. https://doi.org/10.30998/simponi.v0i0.428 